\title{
ABSTRACT \\ Otherness and Self in Latvian Theatre: Changes at the Turn of the Nineteenth Century
}

In the article, political and historical interpretations of the first play in Latvian, an adapted translation of Ludvig Holberg's Jeppe of the Hill (1723, Latvian version 1790) are explored. Although the play has been often interpreted as a work of anti-alcohol propaganda, the article argues that the political motives of the play are no less important. Translated into Latvian during the time of the French revolution, the play mirrors the tense atmosphere of the revolutionary years and reflects changes in Latvian peasant identity. While translating, Baltic German pastor Alexander Johann Stender changed the play's setting to the late

eighteenth century Courland and added new details, emphasizing the social conflict of the play as an ethnic one. It has been argued in the article that since

'class' in the Baltics was divided along national lines, the difference between peasants and masters was also the difference between Latvians and Germans, so class and ethnicity merged. When the peasant and the nobleman switch places in the play, this symbolizes a change in the Latvian-German colonial relationship.

The colonial interpretation allows for a characterisation of the protagonist as a desperate imitator - a colonial subject who loses his identity as a serf and is not able to form a new identity in any way other than by copying the colonialist oppressor. But this mimicry turns into ridicule, hence the play acquires a political meaning as it implicitly shows the disastrous consequences of revolutionary protest. Therefore, the play can be read as a part of the discussions about the Baltic Enlightenment emancipation project and as a hidden debate on serfdom and the colonial framework of the Courland society.

Keywords: Latvian literature, Baltic Germans, Ludvig Holberg, French revolution, Baltic enlightenment, serfdom.

BIOGRAPHY

Pauls Daija, PhD, studied literary theory and history at the University of Latvia (UL) and at the University of Freiburg (Germany). He has worked as lecturer at the UL (2008-12) and researcher at the Institute of Literature, Folklore and Art, UL (2012-present). Daija is also editor-in-chief of the journal of humanities Letonica (2012-present). He has published articles in English, German, Russian and Latvian about the history of Latvian and Baltic German literature in the eighteenth and nineteenth century and participated at conferences in Germany, Russia, and the USA. He translated Peter Burke's Cultural Hybridity into Latvian (2013), and is author of the book Enlightenment and Cultural Transfer: The Making of Latvian Secular Literature (in Latvian, 2014). pauls.daija@gmail.com 


\section{Otherness and Self in Latvian Theatre: Changes at the Turn of the Nineteenth Century}

\section{PAULS DAIJA}

This article invites its reader to rethink the possibilities of the historical and political interpretations of Tas semneeks, kas par muischneeku tappe pahrwehsrsts (The Peasant who Became a Lord), a revised translation of Ludvig Holberg's early enlightenment comedy Jeppe paa Bjerget eller den forvandlede Bonde (Jeppe of the Hill or the Changed Peasant, 1723), which was also the first play in Latvian. The translation was by Alexander Johann Stender (Stender the Younger, 1744-1819) and published in 1790. A Lutheran pastor and an active member of the popular enlightenment (Volksaufklärung) movement, Stender took an active part in Latvian secular literature during the turn of the nineteenth century and published a series of literary works including poetry, short fictions, translations and political treatise.

This play has often been staged as a work of anti-alcohol propaganda. However, the fact that the Latvian translation was published six months after the storming of the Bastille should encourage readers to place the play in the broader context of the Enlightenment. It is not just a play written by Holberg, nor a play translated and revised by Stender it is a play implicitly, but imminently written from within the Enlightenment and French Revolution, which explores the convoluted paths leading to the construction of a Baltic peasant/serf identity during the late eighteenth century. The aim of this article is to demonstrate how the Latvian adaptation of the play gave new meaning to the original text and potentially transformed Holberg's message by moving the setting of the original plot to late eighteenth century Latvia.

\section{THE CONFLICT OF THE PLAY}

The fable of the play is as follows. A poor peasant immersed in alcoholism, Behrtuls ${ }^{1}$ (Jeppe, in original), is sent to market by his domineering wife, but spends all of his money on vodka in a pub and falls asleep. A passing nobleman notices him in his drunken state and decides to play a trick on him. He brings Behrtuls to the manor and has him dressed in fine clothes. Upon awakening Behrtuls believes that he is a nobleman, and amuses the people of the manor with his clumsy behaviour and assaults on his former wrongdoers. Having once again succumbed to drunkenness, Behrtuls falls asleep and is brought back to the place where he was found. He wakes, believing that he has been in paradise, but then is called to court to face a charge of "burglary" from the manor house. The court case proves to be another gag - Behrtuls is sentenced to death by hanging, but his punishers just send him to sleep.

In the final scene, the master utters his thoughts on the moral of the play. ${ }^{2}$ Danish theatrical interpretations have long made use of the ritual logic of the carnival that takes over the comedic events after Behrtuls is transported to the village. The carnivalistic interpretation of the play has been more widely commented on by Danish theatre researcher Bent Holm, who participated in the staging of the comedy in 1992 in the exhibition of carnivalistic conception at Aarhus Theatre. ${ }^{3}$ Although a direct link between the poetics of the carnival and the eighteenth century does not exist, it is useful to refer to Bent Holm's interpretation in discussing the Latvian adaptation of Holberg's play. 
In the exposition of the play, the lowest member of society, the Fool, becomes "king for a day" and, in accordance with ritual, turns the world upside down under his absurd leadership. At the end of the carnival, a false trial ending in the 'execution' of the King/Fool reverses the chaos. Behrtuls and the nobleman represent the ritual antipodes of the carnival - the Fool and the Father. This corresponds to the phase of decline of the modern carnival, when it becomes a form of court celebration and masquerade. ${ }^{4}$ The disguising of Behrtuls is also an unusual court celebration in caricature, an amusement for the aristocrats at the manor. This is significant in the context of this text because ending the carnival with the ritual renewal of the universe, represented in the play by improvised gallows, seems to be the main reason for the structure of Holberg's play:
"Holberg is not a free spirit of his era, he is related to the feudal century."5 Being the progeny of patriarchal absolutism, Holberg diverges cynically from the fable about the beggar who comes to power and begins to rule wisely, as, for example in One Thousand and One Nights, a story with an identical motif. The topsy-turvy structure of the carnival serves as a frame to show that only a despotic, strict, and patriarchal form of state administration can make its inhabitants happy; they are 'simple people' who would otherwise perish as a result of anarchy. This is the logic at the root of many variations of this story in the trivial literature of Europe, but especially of Utopia (1640), ${ }^{6}$ written by German Jesuit Jacob Bindermann, which directly inspired Holberg.

On the scale between 'high-brow' and 'lowbrow' literature throughout various literary peri-

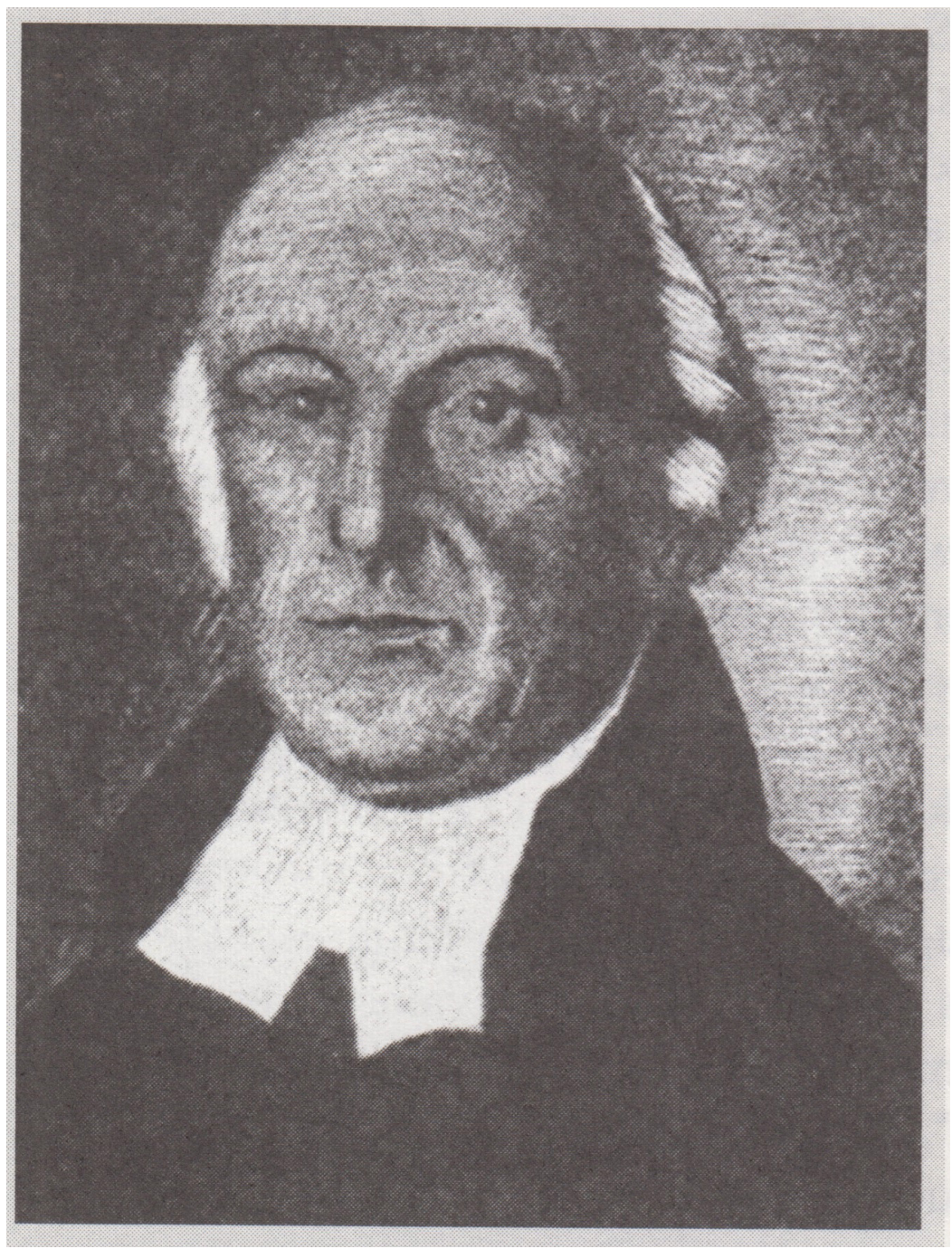

Fig. 1. Alexander Johann Stender. 
ods, Holberg's play has often been judged as being at the low end, creating the misleading impression that the topic of the play is not worthy of attention. However, it is more than clear that the creative works of Holberg, "the Danish Molière", deserve greater respect. It is not merely the political aspect of this play that deserves attention, but the fact that the political is only one of several aspects that justifies our esteem. The text is worthy of interest precisely because of its polyphony - it tells a number of different stories simultaneously giving rise to various interpretive possibilities.

\section{TWO STORIES: ALCOHOLISM AND A PARODY OF THE REVOLUTION}

Alcoholism characterises the surface level of the play, it is the first story told. However, reducing the play to anti-alcoholism propaganda would mean stopping at half a reading. The play consists of at least two stories. The second story told by 'the peasant who became a Lord', is no less important to Stender and has no connection to alcohol. It is an identity story, a burlesque created by the trick of changing clothes. The story can be formulated in one sentence, as has often been done. For example: "The main idea of the play - a peasant cannot be a lord, each must live in his own estate."7 Or else: "A peasant should remain a peasant. This is Holberg's main idea: he who turns away from God's commandments, deserves scorn." 8

The context of serfdom was also important in Denmark during Holberg's time. The escape of the peasants, "the delirium of freedom" is perceived as a threat to the social order. This aspect also becomes significant in Holberg's play. The Revolutionary mood that resonates with the intellectual atmosphere of the 1780s and 1790s in Courland, aggravates the socio-political perspective of the play already present in Holberg's original intent.

Furthermore, the Latvian translation of the play was published during the French Revolution, when the changing social order turns from farce in art to tragedy in life - at least one part of European society sees it this way. Although there are no references to actual events in the play, they nevertheless provide a framework for how the play might be read and understood during the time of publishing. ${ }^{10}$ Holberg's text, only metaphorically linked to the Revolution, has inspired revolutionary interpretations in Scandinavian theatre, mainly in connection with the Russian Revolution of 1917. ${ }^{11}$ Unfortunately, there is no evidence as yet that Holberg's play has been staged in Latvian theatres as a play about political revolution. Latvian productions cannot be compared to the 1934 staging of Holberg's play at the Oslo theatre, where the set design and stage effects, inspired by Vsevolod Meyerhold and Erwin Piscator, grow into a political pathos of Jeppe wearing a red revolutionary scarf. ${ }^{12}$

The play can be read simultaneously as part of the Baltic Enlightenment emancipation project and as a hidden discussion on serfdom and the colonial framework of the Latvian Enlightenment. (Serf-

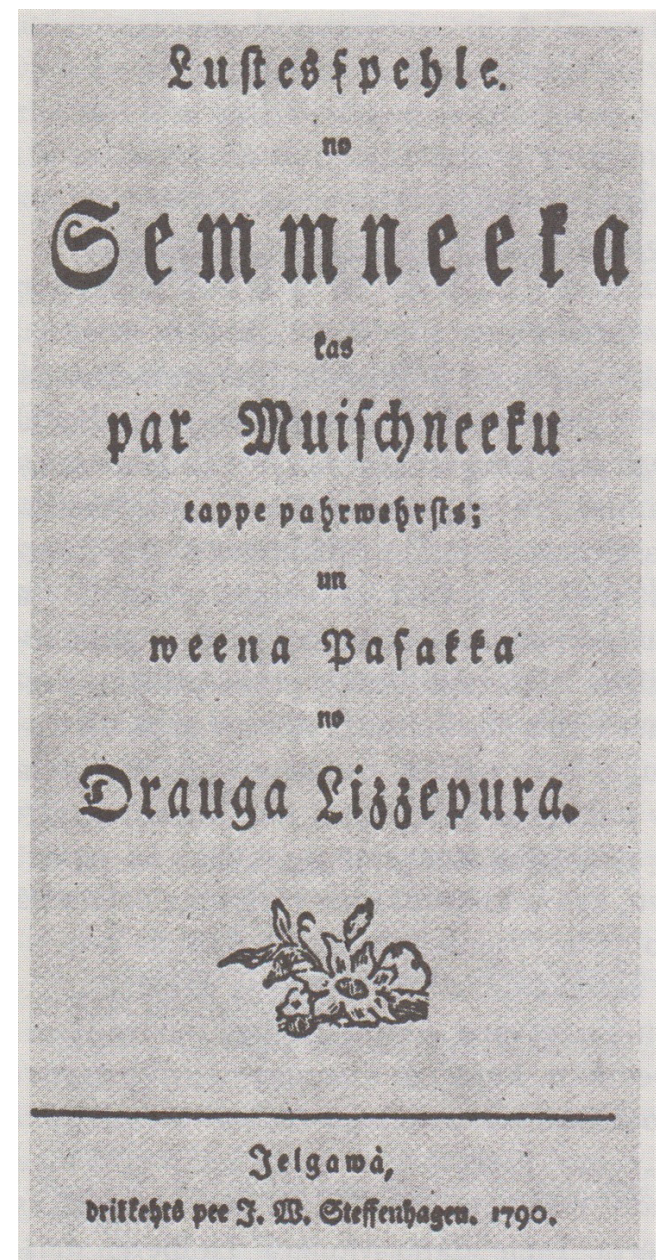

Fig. 2. Cover of the book A Play about a Peasant (Lustesspehle no semneeka, Mitau, 1790) by Alexander Johann Stender. 
dom was abolished in Courland in 1817.) Thus, it illustrates the peculiarity of translated Latvian literature of this era, where even neutral motifs gain ethnic and colonial connotations once translated and adapted into the Latvian language. This fear is very well illustrated by the comments of Rigan literary critic J. H. Neiendahl in the second half of the eighteenth century. Being a supporter of enlightenment ideas, he states that, "serfdom is an unnatural state", but at the same time he doubts whether peasants should be released from serfdom immediately. Releasing them should be postponed because, under the "unnatural" circumstances of their lives, peasants have become so brutal that "freedom for them would mean the same as a razor in a child's hands". ${ }^{13}$

Of course, the question of whether or not Latvian peasants are ready for freedom is not the same as the question of a peasant becoming a nobleman. These ideas, however, do not exclude each other. In popular discussions of that era these ideas converge, because both are a danger to the social order.

Since 'class' in the Baltics is also divided along national lines, the difference between peasants and masters is also the difference between Latvians and Germans in the social consciousness, so these concepts have been used synonymously in public debates. In the Latvian translation of the play, the space and character system of the play transforms and new connotations are introduced into the peasant-nobleman dyad that are specific to the translator's place in time: when the peasant and nobleman trade places on stage this symbolizes a change in the Latvian-German colonial relationship.

\section{THE LITERARY CONTEXT OF THE LATVIAN TRANSLATION}

It is only logical that the hysteria inspired by revolution in the social atmosphere of Courland and Livonia in the 1890s also exacerbated discussions on the annulment of serfdom. The explosion causing tract by Garlieb Merkel, Die Letten, vorzüglich in Livland am Ende des philosophischen Jahrhunderts (Latvians, especially in Livonia at the end of the philosophic century, 1796), a unique outlier in contemporary radical enlightenment literature, gives an apoc- alyptic view of the future of the revolution caused by Latvians oppressed in serfdom. "The nation is no longer a slavishly obedient dog, which can be driven into chains with beatings. It is a tiger, gnawing his chains in silent anger, yearning for the moment to tear them off and wash his shame in blood," warns Merkel. He continues to sketch the revolution: "There would be violence that would make hearts tremble in horror. All estates and towns would be plundered and burned down. [...] All Germans would be murdered, and Latvians, sunk into bestiality, would be expunged by hunger and sword in their forests." 14 A sense of revolution was spreading in the intellectual debates of eighteenth century Courland and Livonia. By translating Holberg's play at such a time, Stender does not have to work hard to adapt it to the spirit of the Era. This is done by the Era itself. "After the ignition of the French Revolution, any opposition against enlightenment ideas and rationalism were transformed into a chain of attacks," Aleksejs Apinnis reminds us. "Rationalists themselves became cautious, reminding in their books that freedom after the French example would bring ruination to peasants." 15

This perspective allows us to see that the play reflects "freedom after the French example" - a miniature revolution. Unlike the work of Alexander Radischev, who was accused of Jacobinism Путешествие из Петербурга в Москву (A Trip from Petersburg to Moscow, also written in 1790) - Stender would certainly not choose to justify a peasant who rebelled against his master. ${ }^{16}$ Rather, he chose the same perspective that Johann Wolfgang Goethe took in a lesser-known comedy, Der Bürgergeneral (The Citizen General, 1793). Goethe took an anti-Jacobean perspective, but also simplified the revolution, transforming it into comedy. In Goethe's play, the impostor and Jacobite Schnaps (der Schnaps, 'liqour' in German) is the typological parallel of Behrtuls the drunkard, pretending to be a representative of revolution. He is a guest at a farmhouse and, in an improvised play, The Nobleman against the Citizen smashes the peasant's storeroom. The local landlord punishes the revolutionary adventurer for creating a mess. ${ }^{17}$ By making use of comedic expressions and depicting a miniature social revolution in this Revolutionary Era play, the 
harmonious father-child relationship between the landlord and his peasants is re-established. It is no accident that many authors found comedy to be the perfect genre for portraying counter-revolutionary sentiment in revolutionary events. "The interpretation of revolution as comedy, farce, or grotesque has a diluting effect on the dominant point of view; in spite of the horror of the story, portraying the event as a farce gives it a tragic magnitude, the sublime character of a natural disaster," ${ }^{18}$ concludes German literary scholar Christiane Leiterlitz as she characterizes the reception of revolution in European literature. It is no accident that a comical winebibber, cuckold and lazybones is the person who breaks the order.

\section{THE REVOLUTIONARY AS PUPPET}

A revolutionary interpretation of the Latvian translation allows readers to explore the interrelationship between literature and the milieu in which it is written. "What will happen if the "common people' acquire 'freedom'?" asks the "naively optimistic" Enlightenment Era German who, from Prussia to the Baltic States, has always striven not to brutalize the body, but to enlighten the mind. ${ }^{19}$ What will happen, if scenes of the French Revolution are repeated with us? (At that time everybody outside of France was asking this question.) What chaos would it bring? The aristocracy would loose its status and its workforce, and those formerly oppressed would not know what to do with their freedom; all will become victims. ${ }^{20}$ This atmosphere of quandary and panic can be felt in fragments of German-Baltic correspondence. ${ }^{21}$ This hysteria eventually evoked a desire in the aristocracy to perceive the revolution as a "single day" event, but the political chaos was like the chaos of the carnival. Actual Revolution Era events are compared to the world turned upside down, for good reason. ${ }^{22}$

Nevertheless, the question of importance is: is Behrtuls really a revolutionary as suggested by the use of the red neckerchief in the Oslo staging? The answer to this question is both simple and ruthless.

Of course, Behrtuls is not a revolutionary. $\mathrm{He}$ does not stage the 'riot' himself; he is a puppet. Behrtuls could never rebel against his master of his own accord, only in his imagination or drunkenness. Analysing the 'surprising passivity' of the main character of the play, Bent Holm emphasises that his every wish is focused on 'escaping' into fantasies and dreams, into a surreal dimension under the influence of alcohol. ${ }^{23}$ In this case, the text of the play coincides precisely with the situation of the Latvian peasant during the French Revolution. Behrtuls is not the 'tiger' Merkel describes; but according to Juhan Kahk - none of the eighteenth century peasants were. ${ }^{24}$ This was so not only in the Baltic States, but also in the rest of Europe. "I stick to the fact that Germany is not ready for a revolution," writes Georg Forster, an eighteenth century publicist who favoured revolution. Of the German peasant he says: "Our vulgar, poor, uneducated nation can only be angry, but not hold it together." 25 The imperative to act that Behrtuls does not possess, but eventually could possess, has been projected on him. If there were a possibility to talk about 'rebellion', it could only exist in the implicit political discussion of the play and not at the level of psychology.

Thus, the Lord becomes the stage director and allows Behrtuls to take his place. The Lord allows Behrtuls to transform himself from a "pig" 26 into a "tiger". He is not changed into a revolutionary, but into the property of revolutionaries in order to see "what happens after a bast shoe turns into a boot" (p. 41). It is necessary for Behrtuls to act as the "main character" of the play for only a short period, for the real hero, and the real central person, is the Lord himself. He willingly chooses to stay in the shadow while the trick is played on Behrtuls, only revealing his hand at the finale. If, before Bertuhls' transformation, the revolutionary experiment is still presented as an innocent joke ("A Manor Lord's amusement", ${ }^{27}$ as characterised by Andrejs Johansons), the Lord himself commenting that it will be a jolly distraction for the manor staff and maids, after the transformation, it is clear that Behrtuls has only been necessary as a prop to give the Lord and the others a chance to see where revolution, freedom and democracy might lead through an empirical experiment: decisions such as are made by 'emancipated fools' are dangerous and irresponsible, they create violence and arbitrariness. When the hitherto suppressed peasant-villain ascends to 
his Lord's seat to administer the manor as he sees fit "becoming an arrogant tyrant in his imagination", ${ }^{28}$ the event, the sceptics warned about, takes place thanks to the French Revolution. A former revolutionary becomes a young despot and instead of a longed-for democracy, an even crueller regime arises. ${ }^{29}$ By punishing the revolutionary by [fake] hanging, the landlord can be seen as a diminished, yet enlightened copy of the monarch, re-establishing the habitual order. This project provides the lens through which many people would like to perceive the revolution. Stender's play portrays the revolutionary as the aristocracy wants to see him, namely as the trauma-inducing catalyst for the revolution.

\section{IDENTITY STRUGGLES:THE WISH TO BECOME GERMAN}

The problems outlined here end in a seemingly insignificant episode in the first act of the play when we witness a conversation between Behrtuls and the bartender Mauschels. It is not merely the exchange of jokes, which it, at first glance, appears to be. Their dialogue serves as a prologue to the main conflict of the play: getting into paradise and becoming a Manor Lord/German. At one point, a heavily drunken Behrtuls begins to speak in broken German. The bartender expresses his wonder of Behrtuls' knowledge of German, to which the peasant answers: "I speak [German] only when my head gets warm." To which the bartender answers: "Then you shall drink every day and you shall become a German.” (pp. 17-18)

This situation will soon become 'reality', but the characters do not yet realize it. Two important details draw our attention. First, Behrtuls' desire to speak German is caricatured. As an early criticism of the "wannabe German" in Latvian literature, this episode shows that knowing "German [...] gives him [Behrtuls] a reason to brag and show himself to be a wise man". ${ }^{30}$ Second - Behrtuls is not ready; he speaks German poorly and only has the strength to rise up against the lord of the manor when under the influence of alcohol. This is the same strength that we see in the bleary look of Merkel in the incipient French revolution. The Jewish bartender says these significant words: "Then you shall drink every day and you shall become a German." This phrase is not just a word play. The original play contains no such phrase; it has been added by Stender. What does he mean by it? What does it mean for a Latvian peasant to become a German?

It is known that the concept "a German", at that time, did not just have an ethnic connotation. To be "German" in the Baltic States is more than just a national identity: it is also another social class. To become a German means to escape the peasant class, to obtain an education and to rise above the lowest level of the social strata. "Social mobility and status was largely determined by language [...] [The German] language became an indication of social position and of the political authority of the dominant German Baltic minority." 31 Later, after the abolishment of serfdom, Baltic German pastor Christian Launitz remembers: "Until now, some of us had been striving outwardly to resemble the Germans, because the Germans were free." 32 The peasants' wish to become German has often been criticised in texts addressed to Latvians as another threat and distortion of the fragile social order. "The Peasant Who Became a Lord" is no exception. Of course, such criticism is possible because throughout the eighteenth century and up to the mid-nineteenth century Latvians are primarily perceived as a social and not an ethnic group.

What is the meaning, then, of bartender Mauschels causally absurd advice? It means exactly what it says - he is commenting on the impossibility of Latvians becoming Germans, the absurdity of such a transformation. Behrtuls could at best become a parody of a German Lord, a "wannabe German", as he is already portrayed in the dialogue. If a Latvian becomes a German, it unsettles the natural order of things. If it does happen though, the world is turned "upside-down" and becomes the carnival Mikhail Bakhtin wrote about. Stender has now added clear didactic connotations to the text of the play by interpreting as absurd the emancipation project, which is associated with undermining the socio-political and national order. However, the poetics of the carnival complicate these issues even more. 


\section{DANGEROUS MIMICRY}

Behrtuls' inadequate behaviour only partially corresponds to the common stereotype of the "rude peasant" and his clumsiness in the Lord's manor. ${ }^{33}$ However, the clumsy one here is not simply a peasant, rather a peasant who believes that he is a landlord and proceeds to behave as one. Behrtuls' farce is not based in his "peasant-ness", but rather in his "landlordish" behaviour, conceptually at least. He begins to imitate his landlord, mimicking his characteristics. If the landlord lives in prosperity and his table is richly spread, Behrtuls not only requires the same, but also eats as much as possible. If the landlord beats his inferiors, Behrtuls not only beats them, but also gives the command to execute them - all of them. If the landlord exercises his right to the first night, Behrtuls does not limit himself to the first night only, but begins with the keeper's wife, with plans to gradually consummate his rights with others.

As a result, we get a landlord who is more loathsome than any that Garlieb Merkel might borrow from real life. This transformation is especially exacerbated by Behrtuls' monologues, which initially lead the audience to expect rational decisions. Indeed, just after his transformation Behrtuls talks like a revolutionary, like a "villain, who begins to realize his position and hates his users". ${ }^{34}$ His pathos is that of a downtrodden peasant who desires justice: "I know how you sweat us poor peasants. [...] You milk the cow, but I only have its horns in my hands. If the world were to remain like this, junkers ${ }^{35}$ and keepers would become landlords, and landlords would end up poor. Your barns are full of all manner of grains and things, but the peasant does not have even a hunk of bread." (p. 39) Latvian scholar Viktors Hausmanis, ${ }^{36}$ interprets Stender's use of such statements in the play not as ironic, but as providing a rational motivation for Behrtuls' actions. Each protest involves risk. Therefore, Behrtuls' rational path imperceptibly turns into a darkened desire for revenge, which in turn transforms his implementation of justice into absurd and grotesque acts of violence. The paradise Behrtuls has entered becomes an infantilized space - a place where there is no need to think or be responsible. Eventually Behrtuls chooses to revenge himself on his former oppressors instead of acting rationally.
The colonial interpretation of the play allows for a characterisation of Behrtuls' as a desperate copycat - a colonial subject who loses his identity as a serf and is not able to form a new identity in any way other than by copying the colonialist oppressor. However, this mimicry turns into ridicule because his copy is disdainfully ironic. Similarly, the pathos of revenge embodies a typical postcolonial situation: the subaltern acquires new cultural material from colonialists, then suddenly turns against them, his 'creators', denying their 'alien' culture, all the while conscious of the fact that by doing so he denies a part of himself. However, the experience of cultural acquisition is inseparable from the experience of colonial violence; there is no other way.

The central conflict of the play is Behrtuls' feeling of "the great injustice, dissatisfaction with who he is and what he has". ${ }^{37}$ Roberts Kroders admonishes his readers that farce should not overtake this feeling. The character of Behrtuls draws on his unconscious desire to become a full member of society, but also to be something more than simply a peasant with no national affiliation - he desires to acquire an identity of his own. When we examine the play from the point of view of a Latvian desiring emancipation, the problem does not lie in "becoming German", but in the situation where, if not the only, then at least the most obvious way forward is this lame and blasphemous grotesque. Getting into heaven means turning Latvian peasants into German noblemen.

\section{DIDACTIC LAUGHTER}

The finale of the play is fascinating in its construction. Behrtuls returns to the pub to continue drinking and drinks himself blind to the future. His alcohol problem has not been solved, since it is only one of the issues of the play. The final scene consists of a dialogue between the lord and the manor staff, who discuss the possibilities of improving the situation of the peasants and enhancing the earnings of the manor in a temperate and apolitical way. "From this drunkard Behrtuls we can learn what happens when a bast slipper becomes a boot," says the lord. "God forbid that such people would become rulers, then nobody would be safe.” (p. 41) Everything 
stays the same. It might seem that the play offers no constructive answers to the issues raised before; Holberg's original really does not provide any solutions, but Stender revises and supplements the content of the play in such an aspect, though his surreptitious work might pass unnoticed, as has been the case until now. The most important didactic and political capacity of the play is hidden in these supplements and evoked by the last words, the last sentence of the play the landlord speaks to the junker: "The laugh if not otherwise then has helped me to enforce sooner what I have only kept in mind, and if I notice that this new order do me and others good, I will give you my best horse.” (p. 62)

The "laughter has helped", meaning a lesson has been learned from the carnival. Stender has made this carnival enlighteningly didactic. Unexpectedly, though, this is not the lesson of Holberg's original - that everybody "should remain in his or her social class." This is understood as a matter-of-course - at least for the elite and for Stender. His changes to the moral of the play are not that obvious. With the "new order", the landlord denotes his law reform project in the quotation; these things are discussed many times in the Latvian text of the play, but they are not in the Danish original, nor are they in the German in-between translation. With the one original phrase by Holberg, in which the landlord notes that the tap-houses should be outlawed, Stender constructs a series of reforms. The question, "In what way might I make my peasants wealthy?" contains two reform projects proposed by the landlord in his preliminary plan. The first has to do with limitations on the sale of vodka. The second is fully quoted: "I also want to relieve my folk - and no landlord shall ever be authorized to ask more from them than it is agreed upon. Though at first my income will be smaller, but later, as my people become wealthier, I shall possess more." (pp. 61-2) We can feel that in this sentence the voice of the landlord is replaced by the voice of Stender: here no landlord is speaking, but instead Stender addresses landlords (hence "no landlord"). The same idea is repeated later in the play: "People should fend for their own good and their own lives, and should save wisely, all works shall be written down and no landlord shall have the right to punish greatly, to parboil them, and to ask more from them than is settled and written in the books. After noticing such a thing, the people would do their work with greater pleasure and landlords shall become richer if the peasants are wealthier - and the blessings of God would spread across the land." (p. 89)

Stender's attempt to rationalize the plot, to solve it with a logical response is typical of the Revolutionary Era, as it hints at the destructiveness of revolution: the elite is forced to realize that only after improving the living conditions of 'the people' will they decrease the risk of riot. ${ }^{38}$ Stender's search for identity and his inability to be a "Latvian friend" and "noble friend" at the same time, is colourfully articulated in his early literary works of the 1890s. Latvian literary scholar Benedikts Kalnačs sees this direction, which could be "translated as an invitation to a peasant expression of frustration" ${ }^{39}$ in Stender's poetry as well. Discovering such invitations in the play is much more difficult. However, by proposing reforms not yet implemented in real life as a solution for Behrtuls issue, Stender draws an implicit, yet obvious criticism of the conservative noblemen. By binding the moral of the play with real reform projects, Stender indicates his own confusion in the face of social reality and his wish to merge the concept of serfdom with the new liberal ideals. In the context of the Enlightenment such an approach is considered to be evolutionary instead of revolutionary. Or, quoting Friedrich Wilhelm Kade, ${ }^{40}$ this attitude recalls the Latin phrase festina lente - hurry slowly. The much discussed question regarding the acceptance of serfdom giving Stender's audience a chance to talk about the Enlightenment, will not be further explored in this article. ${ }^{41}$ However, seeing how freedom is opposed to the social order, we can ask, whether it is possible to synthesize the ideals of a class society with the ideals of equality in Stender's popular enlightenment project? The answer lies in one of the sentences in the last pages of Stender's book.

Stender is able to talk about late eighteenth-century problems that are central to all enlightenment authors through the character of Behrtuls, but his choice of vehicle, the play, makes it possible to lead the audience toward certain inferences, sometimes balancing on the narrow blade of expressing his 
views between the restrictive and emancipatory tendencies of the popular enlightenment. If, through text, it is only possible to speak about revolution metaphorically, then Stender's reform project, transforming Holberg's original beyond recognition, can only be explained by revolution.

To what extent can the political implications of the play be generalized? In the introduction of the article, I pointed out that the political voice of the play should not dominate over others in our reading of the play: the political story of the play and its meaning are inseparable from the polyphony of interpretations the play is devised to present, which makes it possible to forget or dismiss the political story. Therefore, any generalizations that claim the moral of the play is the same as its message are subject to revision. We would do better first to characterize the era in which the play was translated and, second, the mythic and open structure of the comedy itself. The structure Holberg chose makes the play suitable for the dissemination of political ideas, rather than being a play with political subject matter. Herein lies the popularity of the play.

\section{CONCLUDING REMARKS}

The play has become one of the most popular texts of enlightenment era Latvian literature because of the genre, rather than the problems it addresses. In Stender's era, Latvian theatre did not yet exist. His choice of writing a play remains an enigma to this day. A partial explanation might be a pretentious wish to demonstrate his ability in a genre "not yet adopted" by Latvian authors. Another explanation may be linked to the unverifiable theory that the author wished to stage his play in one of the private manor theatres, ${ }^{42}$ making the German elite, not the Latvian readership, the target audience of the play. But let us not forget that in Revolutionary Era France and elsewhere in Europe, folk theatre had become a means of propaganda used to express both Jacobean and counterrevolutionary opinions.

In this context, "the stage became more important than the public discourse, since it can reach a wider segment of the nation because of illiteracy," 43 emphasizes Leiterlitz. It did not happen like that in Courland and, when the play was staged in 1868, social perceptions had already changed. Since the play has never been staged in Latvian theatres in political context, it may very well be relevant for twenty-first century audiences.

The experience of Scandinavian theatre shows that it is a complicated task to stage twentieth century political interpretations of Holberg. Not only because they require the director to respect the tragedy in the comedy and the comedy in the tragedy simultaneously, but also because of the other contradictions that arise. These contradictions are those of the eighteenth century. At first glance, the simple format of the play makes the urgent political questions of the day seem naive, but it contains a precise caricature of the thesis on the emancipative and totalitarian derivation of enlightenment. If it is, in fact, Holberg's patriarchal absolutism ${ }^{44}$ that inspires Stender.

To solve these controversies clearly would be the same as to ignore them. Perhaps nothing can demonstrate the paradoxes of the Enlightenment Era better than the Brechtian staging of this play at Oslo's Riksteater in 1984, where both lord and peasant are shown to be victims of the same system. ${ }^{45}$ This staging did not try to aestheticize the "complexity of the victims". In between the lines, the audience is led to understand that emotional identifying with one side or the other in the conflict between Behrtuls and the Lord is a misunderstanding of this conflict. This probably applies not only to the play, but also to the history of the relationship between Latvians and Germans during the Enlightenment Era as a whole. If the political narrative is worth remembering, then it is because it illuminates the programmatic thinking of enlightenment literature and the problematic aspects in the construction of the identity of indigenous Latvian peasants. 


\section{NOTES AND REFERENCES}

1 The name of the protagonist was changed to Bērtulis in the twentieth century following the changes to the rules of written Latvian.

2 The Latvian translation is based on the German translation of Holberg's play and it contains several additions and reshuffles, adopting the text to local conditions and the translator's opinion. But these are (with some exceptions) episodic, and the translation in general is trustworthy, though not equivalent to the original. The division of the play into acts has been changed. Māra Grudule has compared the Danish original, the German intermediary translation, and Stender's translation. In this article the author builds on Grudule's as yet unpublished research.

3 Bent Holm, "'Jeppe of the Hill" - A Dream Play: A Historical and Dramaturgical Interpretation" in NorthWest Passage. Yearly Review of the Centre for Northern Performing Arts Studies, no. 1, 2004, pp. 11-25.

4 Mikhail Bakhtin, "Karnevāls un literatūras karnevalizācija" ("Carnival and the Carnivalzation of Literature") in Grāmata, no. 6, 1991, p. 51.

5 Kroders, "Ludvigs Holbergs: Žūpu Bērtulis" in Latvijas Vēstnesis, 12 December 1924.

6 Bent Holm, "Ludvig Holberg and His Double: Holberg in Scandinavia" in Ludvig Holberg: A European Writer: A Study in Influence and Reception, Sven Hakon Rossel, ed., Rodopi, Amsterdam, Atlanta 1994, p. 193.

7 Valija Labrence, "Feodālisma iršanas un kapitālisma tapšanas periods" in Latviešu literatūras vēsture. 1. sēj. Latviešu folklora un literatūra lìdz 19. gs. vidum, LPSR ZA izdevniecība, Rīga 1959, p. 566.

8 Kroders, op. cit.

9 Garlieb Merkel, Izlase (Selected Works), Liesma, Rīga 1969, p. 101.

10 Commenting on the wide reflections of revolutionary events in Baltic German periodicals, Andrejs Johansons adds that in the countryside various periodicals "also reached and influenced, although slowly and indirectly, the consciousness of Latvian people". (Andrejs Johansons, Latvijas kultūras vēsture, Daugava, Stockholm 1975, p. 74.)

11 Holm, "Ludvig Holberg and His Double", op. cit., p. 214-5.

12 Ibid.

13 Johansons, op. cit., p. 30.
14 Merkel, op. cit., pp. 139-40.

15 Aleksejs Apīnis, Grāmata un latviešu sabiedrība līdz 19. gadsimta vidum, Liesma, Rīga 1991, p. 101.

16 "Peasants who killed their masters were murderers. But wasn't this murder enforced? Wasn't there reason? If, according to arithmetic, a third number arises from two given numbers, then this event arose from necessity. The innocence of the murderers was as clear as a multiplication table to me." (Alexander Radischev, Ceļojums no Pēterburgas uz Maskavu, Liesma, Rīga 1978, p. 93.)

17 More on the effect of the revolution in Goethe's opinion: Hans-Jürgen Schings, "Kein Revolutionsfreund: Die Französische Revolution im Blickfeld Goethes" in Goethe Jahrbuch, Wallstein, Göttingen 2009, pp. 5264.

18 Christiane Leiterlitz, "Die französische Revolution im Spiegel der Literatur" in Wende von der Aufklärung zur Romantik 1760-1820, Horst Albert Glaser, György M. Vajda, eds., Hojhn Benjamins, Amsterdam, Philadelphia 2001, p. 62.

19 Henry Brunschwig, Enlightenment and Romanticism in Eighteenth-Century Prussia, The University of Chicago Press, Chicago, London 1974, p. 97.

20 More on the reception of the French revolution in the Baltics: Georg Rauch, "Die französische Revolution von 1789 und die Baltischen Provinzen" in Baltic History, Arvīds Ziedonis et al, eds., AABS, Ohio 1974, pp. 99-104.

21 Arveds Švābe, Kāda mācītāja dzīve, Daugava, Stockholm 1958, p. 51.

22 Revolutions-Almanach von 1794, J. Chr. Dieterich, Göttingen 1794, p. VI.

23 Holm, "'Jeppe of the Hill" - A Dream Play", op. cit., p. 16.

24 "We can say that this literary-politic peasant [as created by Merkel - P. D.] represented, quite well, the interests of the real peasant, although real peasants did not know of its existence. [...] The real peasant was more passive, less aggressive and revengeful than his literary peer," writes Estonian historian Juhan Kahk. (Juhan Kahk, ”Der Bauer in der Literatur und im Wirklichen Leben. Die progressiven baltischen Publizisten an der Grenzscheide des 18. und 19. Jahrhunderts und ihr Held" in Der Bauer Mittel-und Osteuropas im sozio-ökonomischen Wandel des 18. und 19. Jahrhunderts, Böchlau, Köln, Wien 1973, pp. 358-63.) 
25 Quoted in: Leiterlitz, op. cit., p. 65.

26 The main character calls himself a "pigs' Behrtuls". (Alexander Johann Stender, Lustesspēle no zemnieka, kas par muižnieku tape pārvērsts, un viena pasaka no drauga Licepura, Steffenhagen, Mitau 1790, p. 25. Further, references to the page numbers are given in the text in brackets.)

27 Johansons, op. cit., p. 531.

28 Kroders, op. cit.

29 Leiterlitz, op. cit., p. 67.

30 Kārlis Kurcalts, "Latviskās drāmas sākums" in Daugava, no. 12, 1933, p. 1127.

31 Andrew James Blumbergs, The Nationalization of Latvians and the Issue of Serfdom: the Baltic German Literary Contribution in the 1780s and 1790s, Cambria Press, Amherst 2008, p. 46.

32 Christian Launitz, No brīvestības un viņas iecelšanas Kurzemē, Steffenhagen, Mitau 1819, p. 58.

33 Johann Heinrich Baumann later wrote a play with the transparent title The Jolly Buffoon in the Market Square (Lustīgais nerris uz tirgus plača, 1863), which makes use of the trope the peasant in the city.

34 Oto Čakars, Arvīds Grigulis, Milda Losberga, Latviešu literatūras vēsture: No pirmssākumiem līdz 19. gadsimta 80. gadiem, Zvaigzne, Rīga 1987, p. 89.

35 I.e. the manager of the manor or the bailiff. 'Junkuri' in the Latvian original.

36 Viktors Hausmanis, Latviešu drāmas sākotne, Zinātne, Rīga 2009, p. 17.

37 Kroders, op. cit.

38 Leiterlitz, op. cit., p. 63.

39 Benedikts Kalnačs, "Daži jautājumu loki ap nemirstīgo Žūpu Bērtuli" in Varavīksne. Literārā mantojuma gadagrāmata, Preses nams, Riga 1994, p. 130.

40 Friedrich Wilhelm Kade, Freymüthige Gedanken über den Nutzen, die Grenzen und Einrichtung des Unterrichts für Letten, Kanter, Königsberg 1794, p. 5.

41 More on problems in defining Baltic enlightenment: Pauls Daija, "Volksaufklärung in der lettischen Literatur des 18. Jahrhunderts" in Deutsch-Baltisches Jahrbuch, no. 63, 2015, pp. 64-71.

42 Johansons writes more on this version, pointing to the popularity of elite manor theatre in Courland, as well as to the lack of information on plays staged there. Johansons does not deny, "there were preconditions that some manors might be able to stage - and maybe even did stage - Stender's 'jolly play’ about Behrtuls.” (Johansons, op. cit., pp. 532-3.

43 Leiterlitz, op. cit., p. 67.

44 Holm, "Ludvig Holberg and His Double", op. cit., p. 191.

45 Ibid., p. 215. 